\title{
Competition and Profitability in the Chinese banking industry: new evidence from different ownership types
}

\begin{abstract}
This paper tests the competition in different banking markets in China (deposit market, loan market, and non-interest income market) using a sample of Chinese commercial banks (state-owned banks, joint-stock banks and city commercial banks) over the period 2003-2013 and further examines the impact of competition on bank profitability for the whole sample and also for different ownership types. The results show that non-interest income market in the Chinese banking industry has a higher level of competition compared to the other two markets during early years of the examined period. The findings further report that in a higher competitive deposit market, Chinese commercial banks have lower levels of profitability. Finally, the results suggest that a higher competitive loan market leads to higher profitability of all these three types of banks while the impact of deposit market competition is significant and negative.
\end{abstract}

Keywords: Bank profitability, Bank competition, GMM, China

JEL classification: G21, C23 


\section{Introduction}

The Chinese banking sector has undergone sustainable and healthy development through several rounds of banking reforms initiated by the government since 1978. The main purpose of these banking reforms has been to increase competitive conditions, enhance stability and improve the performance of the Chinese banking sector. With regards to the competitive condition in the Chinese banking industry, it is noticed that the state-owned commercial banks (SOCBs) ${ }^{1}$ still dominate the industry. However, according to statistics from the China Banking Regulatory Commission (CBRC), the share of SOCB assets in total banking sector assets decreased between 2003 and 2013 to a low point of $43.3 \%$. On the other hand, the joint-stock commercial banks (JSCBs) and city commercial banks (CCBs) have kept increasing in size and in 2013 they held $17.8 \%$ and $10.03 \%$ of total banking sector assets. Therefore, the statistic shows that the competitive condition is still quite low under the consideration that five largest banks hold more than $40 \%$ of total banking sector assets. Table 1 summarizes the assets of SOCBs, JSCBs, CCBs and total banking institutions in China over the period 2003-2013.

$<<$ Table 1---about here>>

The impact of competition on profitability in the banking industry has been documented in the traditional structure-conduct-performance (SCP) paradigm, which mainly argues that in a higher concentrated industry with a lower level of competition, firms tend to collude with each other to obtain higher profit. In addition, there is a large number of literature investigating the impact of

\footnotetext{
${ }^{1}$ There are five state-owned commercial banks in China now including Bank of China, Industrial and Commercial Bank of China, China Construction Bank, Agricultural Bank of China and Bank of Communication.
} 
competition on profitability in the banking industry (Smirlock, 1985; Bourke, 1989; Goldberg and Rai, 1996; Demirguc-Kunt and Huizinga, 1999; Maudos and Fernandez de Guevara, 2004; Athanasoglou et al., 2008; Tan and Floros, 2014; Tan, 2016; among others). In comparison to the traditional SCP hypothesis discussed above, the efficient-structure hypothesis (ES) argues that it is the superior efficiency rather than the collusive behavior that actually leads to an improvement in bank profitability. Accounting cost-income ratio or parametric stochastic frontier estimation is used to derive the bank efficiency. The empirical literature has different findings with regard to the impact of efficiency on bank profitability (Berger, 1995a, Garcia-Herrero et al., 2009; among others). Recently, Tan (2017) investigates the joint impact of competition in different banking markets (deposit market, loan market and non-interest income market) and shadow banking using a sample of Chinese commercial banks over the period 2003-2013. This study contributes to the empirical banking literature, in particular to Tan (2017) by examining the impacts of competition in different banking markets on profitability of different ownership types of Chinese commercial banks (state-owned commercial banks, joint-stock commercial banks and city commercial banks), the evaluation of this would be very important for the financial regulatory authorities to make different policies for different banks. In addition, the current study uses stability inefficiency rather than Z-score to measure the insolvency risk in the Chinese banking industry, which is supposed to provide more accurate results.

The results of the current paper show that in general, there is a higher level of competition in the non-interest income market compared to the ones in deposit market and loan market. Furthermore, it is found that in a higher competitive deposit market, Chinese commercial banks have lower levels of profitability. With regard to the impact of competition on the profitability of different ownership types of Chinese commercial banks, the findings suggest that a higher competitive loan 
market leads to higher bank profitability while Chinese commercial banks have lower levels of profitability in a more competitive deposit market for state-owned, joint-stock and city commercial banks. In particular, we find that in a higher competitive non-interest income market, joint-stock commercial banks have lower levels of net interest margin (NIM).

This paper will be structured as follows: Relevant literature investigating bank profitability will be reviewed in section 2; section 3 presents the data and methodology, which is followed by section 4 describing and discussing the findings and section 5 provides a summary and conclusion of the whole paper.

\section{Literature review on bank profitability}

\subsection{Literature review on bank profitability}

The empirical literature of bank profitability focuses on the US banking industry, European banking industry, Asian economies as well as Chinese banking industry, most of the studies find that the bank profitability is significantly affected by bank size, bank liquidity, bank capitalization, bank credit risk, bank efficiency, bank diversification as well as GDP. Table 2 provides a summary of the empirical studies focuses on countries except China.

$<<$ Table 2---about here >

\section{2 literature review on investigating profitability in the Chinese banking industry}

The profitability in the Chinese banking sector has been extensively tested by the empirical literature. Shih et al. (2007) evaluated the performance of a sample of Chinese commercial banks in 2002 under a principal component analysis. The results indicate that joint-stock commercial 
banks have better performance compared to state-owned commercial banks and city commercial banks. Their findings further suggest that bank size does not have any significant impact on bank performance in China.

Rather than using the principal component analysis, few studies used the fixed or random effort estimator to evaluate the profitability of Chinese commercial banks (Sufian and Habibullah, 2009 and Sufian, 2009; among others).The results of Sufian and Habihullah (2009) suggest that credit risk has a significant and positive impact on the profitability of Chinese state-owned commercial banks and joint-stock commercial banks. In addition, Sufian (2009) uses four state-owned commercial banks and twelve joint-stock commercial banks during 2000-2007 to examine the determinants of bank profitability in China. The results show that Chinese commercial banks with higher levels of credit risk and higher levels of liquidity have higher profitability.

The fixed or random effect estimator is unable to deal with the issue of profit persistence, endogeneity as well as autocorrelation when estimating the determinants of bank profitability, thus, a growing number of recent literature used the Generalized Method of Moments (GMM) estimator to test the profitability in the Chinese banking industry (Tan and Floros, 2012a, 2012b, 2012c). In particular, these studies examined the impact of competition on Chinese bank profitability using 3-bank or 5-bank concentration ratio. The results of these studies do not find any significant impact of competition on bank profitability.

The GMM estimator was also used by Garcia-Herrero et al. (2009) to jointly test the impact of efficiency and competition on bank profitability in China over the period 1997-2004. Rather than using the 3-bank or 5-bank concentration ratio as the competition indicator, they used the Hirfindahl-Hirschman index. The results show that Chinese commercial banks with higher levels 
of efficiency have higher profitability and there is no clear impact of competition on bank profitability in China.

More recently, Tan (2016) examined the impacts of risk and competition on bank profitability in China over the period 2003-2011 under a GMM estimation. This study contributed to the previous studies by using the Lerner index to measure the competitive conditions. This indicator has the advantages of measuring the competition of different ownership types of Chinese banks from the perspective of market power. The results show that there are no clear impacts of risk and competition on bank profitability in China.

Using a sample of Chinese commercial banks over the period 2003-2009, Tan and Floros (2014) investigated the inter-relationships between risk, profitability and competition in the Chinese banking industry, two types of risk are considered which are credit risk and insolvency risk while the competitive condition is measured by the Lerner index. They used the Seemingly Unrelated Regression to analyze the inter-relationships. The results show that there is a negative impact of competition on bank profitability in China while there is no robust impact of different types of risk on bank profitability in China.

Tan (2017) use a sample of Chinese commercial banks over the period 2003-2017 to test the impact of competition in different banking market and shadow banking on bank profitability. The results from Boone indicator show that non-interest income market has a higher level of competition compared to the deposit market and loan market, while the findings from a GMM estimation report that a lower level of competition in the deposit market improves the profitability of Chinese banks and shadow banking also improves the bank profitability in China. 


\section{Data and Methodology}

\subsection{Data}

Our sample consists of data from five SOCBs, twelve JSCBs, and eighty-three CCBs. The sample covers the period 2003-2013 and the bank-specific data is collected from Bankscope database produced by Bureau Van Dijk (www.bvdinfo.com). The industry-specific and macroeconomic variables are retrieved from the website of China Banking Regulatory Commission (www.cbrc.gov.cn) and the World Bank database (data.worldbank.org). Due to the fact that not all the banks have available information for all the years, we opt for an unbalance panel dataset not to lose degrees of freedom. We use two different profit measures which are ROA and NIM. The bank-specific determinants of profitability include credit risk, liquidity, capital, insolvency risk, bank size, bank diversification and overhead cost. All the bank-specific variables are measured by relevant accounting ratios except the insolvency risk, which is measured by stability inefficiency (see methodology for detail). The industry-specific variables include competition, banking sector development and stock market development. With regards to the macroeconomic determinants, we include both annual inflation rate and annual GDP growth rate. Table 3 provides a summary of the variables used in the current study and their expected effects on bank profitability.

Table 4 shows the summary statistics of the independent variables used in the current study. The table shows that the difference in liquidity level of Chinese commercial banks is smaller than the ones for credit risk and capital, while the higher levels of credit risk undertaken by Chinese commercial banks are attributed to the fact that during 2003-2006, there are large volumes of nonperforming loans in SOCBs, especially in the Agricultural Bank of China. Further, the large difference in the levels of capital is attributed to the opening of one joint-stock commercial bank; 
namely, the China Bohai Bank in 2006 which had a total regulatory capital ratio of over 60\%. The data indicates that Chinese banks have big differences in the degree of diversified activities engaged in. The difference in bank size is attributed to the fact that SOCBs are bigger than JSCBs, while CCBs are the smallest. The statistics show further that there is a stronger volatility with regard to the development of the stock market than of the banking sector and the macroeconomic environment. The stronger volatility of stock market development can be attributed mainly to the segregation reform initiated by the Chinese government in 2005 which led to a substantial amount of companies being listed on the stock exchange. By the end of 2007, there were 1550 listed companies on the Shanghai and Hong Kong Stock Exchanges, the value of which reached RMB 32.71 billion, accounting for $132.6 \%$ of GDP in that year.

$$
\begin{aligned}
& <<\text { Table 3--about here >> } \\
& \text { <<Table 4---about here >> }
\end{aligned}
$$

\subsection{Methodology}

\subsubsection{Measurement of competition in different banking markets in China}

The current study uses the method proposed by Boone (2008) to measure the competition. The Bonne indicator holds the idea that the performance of efficient firms is improved and the performance of inefficient firms is weakened by competition. The basic logic of Boone indicator is in line with the argument of efficiency structure hypothesis as developed by Demsetz (1973) which links the influence of efficiency on performance. The performance can be measured by profit or market share. The stronger effect will lead to a more negative Boone indicator. The Boone indicator for bank i can be defined by the simplest equation as follows: 
$L N\left(M S_{k i}\right)=\alpha+\beta L N\left(M C_{k i}\right)$

Where i represents the specific bank, $\mathrm{k}$ stands for a specific bank output, MS is the market share while MC measures the marginal cost. $\beta$ denotes the Boone indicator. In this paper, we focus on the analysis of competition in different markets reflecting interest income activities as well as noninterest generating business, this significantly contributes to the empirical banking literature which just focuses on the examination of the whole banking market or only the loan market. Thus, $\mathrm{K}=$ loans, deposits, non-interest income.

The marginal cost is estimated on the basis of a translog cost function with four outputs (total loans, total deposits, securities and non-interest income) and two input prices (price of labour, price of capital). The specification of the translog cost function is shown as below (Tabak et al., 2012): $L N\left(\frac{C}{W_{2}}\right)_{i t}=\delta_{0}+\sum_{j} \delta_{j} L N Y_{j i t}+\frac{1}{2} \sum_{j} \sum_{k} \delta_{j k} L N Y_{j i t} L N Y_{k i t}+\beta_{1} L N\left(\frac{W_{1}}{W_{2}}\right)_{i t}+\frac{1}{2} \beta_{11} L N\left(\frac{W_{1}}{W_{2}}\right)_{i t} L N\left(\frac{W_{1}}{W_{2}}\right)_{i t}+\sum_{j} \theta_{j} L N Y_{j i t} L N\left(\frac{W_{1}}{W_{2}}\right)_{i t}+\varepsilon_{i t}$

where $\mathrm{C}$ represents total cost of the bank, $\mathrm{Y}$ represents four outputs including total deposits, total loans, non-interest income and securities, W stands for two input prices with W1 representing the price of funds which is measured by the ratio of interest expenses to total deposits, W2 represents the price of capital, which is measured by the ratio of non-interest expenses to fixed assets, two input prices are considered due to the fact that non-interest expenses include the labour cost as well (Hasan and Morton, 2003). In other words, the price of capital considers the factors relating to the price of physical capital as well as the price of human capital. The linear homogeneity is ensured by normalizing the dependent variable and W1 by anther input price W2. The summary statistics of the variables are reported in Table 5. 
The marginal cost of loans can be obtained by taking the first derivative of the dependent variable in the above equation in relationship to the output loans as follows:

$$
M C_{i l t}=\left(\frac{C_{i t} / W_{2}}{Y_{i l t}}\right)\left(\delta_{j=l}+2 \delta_{l l} L N Y_{i l t}+\sum_{k-1 \ldots k, k \neq l} \delta_{l k} L N Y_{i k t}+\theta_{l} L N\left(\frac{W_{1}}{W_{2}}\right)\right)
$$

The marginal cost of deposit and non-interest income can be obtained similarly by taking the first derivative of the dependent variable in the above equation in relationship to the outputs deposits and non-interest income as below:

$$
\begin{aligned}
& M C_{i d t}=\left(\frac{C_{i t} / W_{2}}{Y_{i d t}}\right)\left(\delta_{j=d}+2 \delta_{d d} L N Y_{i d t}+\sum_{k-1 \ldots k, k \neq d} \delta_{d k} L N Y_{i k t}+\theta_{l} L N\left(\frac{W_{1}}{W_{2}}\right)\right) \\
& M C_{\mathrm{int}}=\left(\frac{C_{i t} / W_{2}}{Y_{\mathrm{int}}}\right)\left(\delta_{j=n}+2 \delta_{n n} L N Y_{\mathrm{int}}+\sum_{k-1 \ldots k, k \neq n} \delta_{n k} L N Y_{i k t}+\theta_{l} L N\left(\frac{W_{1}}{W_{2}}\right)\right)
\end{aligned}
$$

\subsubsection{Estimation of stability in the Chinese banking sector-Stability inefficiency}

The current study follows Tan (2016) to estimate the insolvency risk in the Chinese banking industry under the stability inefficiency rather than the Z-score by providing a translog frontier specification as follows:

$$
\begin{aligned}
& \operatorname{Ln}\left(\frac{Z-\text { score }}{W_{2}}\right)_{i t}=\delta_{0}+\sum_{j} \delta_{j} \operatorname{Ln} Y_{j i t}+\frac{1}{2} \sum_{j} \sum_{k} \delta_{j k} \operatorname{Ln} Y_{j i t} \operatorname{Ln} Y_{k i t}+\beta_{1} \operatorname{Ln}\left(\frac{W_{1}}{W_{2}}\right)_{i t}+\frac{1}{2} \beta_{2} \operatorname{Ln}\left(\frac{W_{1}}{W_{2}}\right)_{i t} \\
& +\sum_{j} \theta_{j} \operatorname{Ln} Y_{j i t} \operatorname{Ln}\left(\frac{W_{1}}{W_{2}}\right)+v_{i t}-v_{i t}
\end{aligned}
$$


Where $\mathrm{W}$ represents input prices, there are two input prices which are price of funds (the ratio of interest expenses to total deposits) and price of capital (the ratio of non-interest expenses to fixed assets). Y represents four outputs which are total loans, total deposits, other earning assets and non-interest income. The sub-index $\mathrm{i}$ and $\mathrm{t}$ represent bank $\mathrm{i}$ operates at time $\mathrm{t}$ while $\mathrm{j}$ and $\mathrm{k}$ represent different outputs. The error term $\varepsilon_{i t}$ equals $v_{i t}-v_{i t}$. The first term $v_{i t}$ captures the random disturbance, which is assumed to be normally distributed and represents the measurement errors and other uncontrolled factors, i.e. $v_{i t} \sim \mathrm{N}\left(0, \sigma_{v}^{2}\right)$. The second term $v_{i t}$ captures the technical and allocative inefficiency, both under managerial control, and it is assumed to be half-normally distributed, i. e. $v_{i t} \sim N^{+}\left(\mu_{i t}, \sigma_{v}^{2}\right)$. Higher stability inefficiency indicates higher risk while lower stability inefficiency means the risk is lower.

\subsubsection{Estimation on the determinants of bank profitability}

In general, there are two groups of Generalized Method of Moments (GMM) estimators used to estimate a dynamic model of bank profitability, they are System GMM estimator and difference GMM estimator. Comparing between these two different estimators, the current study prefers the former due to the fact that system GMM estimator is able to address the issue of unit root and produce more robust and accurate results (Bond, 2002). In addition, rather than using a two-step estimator by Ahamed (2017), the one-step GMM estimator is chosen in the current study to investigate the profitability in the Chinese banking industry following Athanasglou et al. (2008). Besides using the one period lag of profitability indicators, through the Sargan over-identifying test, we confirm that the capital will be treated as endogenous variable, while credit risk will be treated as predetermined variable, other variables do not suffer any endogenous issue. In order to make sure there is no second order autocorrelation in the estimation, the predetermined variable is 
instrumented using levels lagged by one year period, while the endogenous variable is instrumented using levels lagged by two years periods. In terms of the choice between firstdifference transformation and orthogonal deviation, the current study follows Yao et al. (2018) and applies the orthogonal deviation. Arellano and Bover (1995) argue that in an unbalance panel data, the average of future available observations of a variable in the transformed data is subtracted by the orthogonal deviation, which means that the gap is not magnified by the method. This study follows and expands the specification proposed by Athanasoglou et al. (2008), which can be expressed as follows:

$$
I I_{i t}=\mathrm{C}+\delta I I_{i, t-1}+\sum_{j=1}^{j} \beta_{j} X_{i t}^{j}+\sum_{l=1}^{l} \beta_{l} X_{i t}^{l}+\sum_{m=1}^{m} \beta_{m} X_{i t}^{m}+v_{i t}+\mu_{i t}
$$

Where i refers to year and $\mathrm{t}$ refers to an individual bank, $I I_{i t}$ represents the profitability indicator for the specific bank at a specific year, $\mathrm{C}$ is the constant term, $I I_{i, t-1}$ is one period lagged profitability. $X_{i t}$ are determinants of bank profitability. They are grouped into bank-specific determinants including credit risk, liquidity, capital, insolvency risk, bank size, overhead cost and bank diversification $X_{i t}^{j}$; industry-specific determinants including competition in different banking markets, stock market development and banking sector development $X_{i t}^{l}$; and macroeconomic determinants including inflation and GDP growth $X_{i t}^{m}$. The unobserved bankspecific effect and the idiosyncratic error are represented by $v_{i t}$ and $\mu_{i t}$, respectively. $\beta_{j}, \beta_{l}$, and $\beta_{m}$ are coefficients to be estimated, while $\delta$ represents the speed of adjustment to equilibrium. Its value ranges from 0 to 1 , with a higher figure representing slower adjustment and less competitive 
structure, while a lower figure indicates that there is a stronger competitive condition and a higher speed of adjustment.

\section{Empirical results}

Tables 6a-6d present the descriptive statistics of the two different profitability measures (ROA and NIM) for the whole Chinese banking industry as well as for different ownership types. The table shows that the profitability of CCBs is the highest over the examined period which is followed by SOCBs while the profitability of JSCBs is the lowest. When looking at the profitability of different ownership types of Chinese commercial banks on a year by year basis, Figure 1 shows that, in general, SOCBs and CCBs have higher profitability than JSCBs.

$<<$ Tables 6a to 6d---about here $>$

$<<$ Figure 1---about here >>

\subsection{The competitive condition in the Chinese banking industry---Boone indicator}

Compared to the competitive condition among the above three different banking markets, it is noticed that over the period 2006-2013, the competitive condition in these three different markets was the same, the main difference is noticed during the period 2003-2005. Figure 2 shows that the competitive condition in the non-interest income market is the highest in general between 2003-2005 compared to the other two markets while the competitive condition in the loan market and the deposit market were the same over the same period.

$<<$ Figure 2---about here>> 


\section{2. insolvency risk in the Chinese banking industry-stability inefficiency}

We look at the insolvency risk of the Chinese banking industry on a year by year basis, which is reflected by stability inefficiency (Figure 3). The figure shows that the risk conditions in the Chinese banking sector over the period 2003-2006 were highly volatile; while during 2007-2013, they reduced. The stronger volatility over the period 2003-2006 can be explained by the fact that there was a large amount of non-performing loans in Chinese commercial banks, especially SOCBs, and that the capital level of SOCBs was quite low. Furthermore, the Chinese government initiated a number of measures to deal with it, such as capital injection and non-performing loan write-off, while the financial crisis of 2007-2008 induced bank managers to be more careful in conducting business. The 2008 Olympic Games held in Beijing further promoted the economic growth of China. The resultant decline in the probability of default decreased the risk and increased the capital level of Chinese commercial banks, which further improved stability in the Chinese banking sector.

$<<$ Figure 3---about here >>

\subsection{Empirical results-Impact of competition on bank profitability}

Table 7 shows the results with regard to the impact of competition in different banking markets on bank profitability in China. The $\mathrm{F}$ statistic shows that the variables in the model are jointly significant while the Sargan test statistic shows that there are no over-identified restrictions. The

results further indicate that the first-order autocorrelation is present for all the cases while the second-order autocorrelation is rejected, which guarantees the consistency of the results. The finding shows that the lag of the dependent variable (both ROA and NIM) are significant and 
positive, which indicates that the dynamic specification of the model is correct, while the significant and positive signs of the lagged dependent variables further suggest that the profitability of Chinese commercial banks in the current year is significantly and positively affected by its previous year's profitability. The values of both of these two coefficients are less than 0.4 , which means that the profitability of Chinese commercial banks does not persist to a large extent. This result is in line with the findings of Tan (2016).

With regard to the bank-specific determinant of profitability, the results report that liquidity is significantly and negatively related to ROA and NIM of Chinese commercial banks, indicating that Chinese commercial banks with higher levels of liquidity have higher profitability. This is in contrast with the findings of Molyneux and Thornton (1992). Our results can be explained by the fact that higher liquidity reduces the borrowing cost for banks, which further proceeds an improvement in bank profitability.

The table further suggests that Chinese commercial banks with lower levels of capital have higher bank profitability in terms of ROA. This result is in accordance with Berger (1995b). Chinese commercial banks have lower levels of capital to some extent can be explained by putting certain amount of capital in engaging in traditional and non-traditional banking activities, a larger amount of business leads to an improvement in bank profitability.

The results indicate that bank size is significantly and negatively related to Chinese bank profitability, as reflected by the significant and negative signs of the variable. This result is in accordance with the finding of Goddard to al. (2001). The negative impact of size on bank profitability can be explained by the fact that large banks are difficult to be managed (Tan and 
Floros, 2012a), which induces a larger amount of efforts and the resulted increase in the cost leads to a decline in bank profitability.

Overhead cost is found to be significantly and positively related to bank profitability in China, indicating that Chinese commercial banks with higher levels of overhead cost have higher profitability. This result is different from the finding reported by Tan and Floros (2012b). however, our results can be explained by the efficiency wage theory, which argues that higher cost derived from higher wage/salary to bank staff is supposed to significantly increase the labor productivity, the resulted improvement in revenue exceeds the labor cost. Therefore, higher overhead cost leads to higher bank profitability.

Our results show that bank diversification is significantly related to bank profitability in China, however, the sign of the variable is different between ROA and NIM. To be more specific, the findings suggest that Chinese commercial banks with a higher degree of business diversification have higher ROA but lower NIM. Due to the fact that ROA focuses on bank's ability to generate income from total assets, which considers both the interest generating business as well as noninterest income activities, on the other hand, NIM concentrates on interest-generating activities only. Our results underline that Chinese commercial banks with more diversified business can generate higher income while more resources/funds used in engaging in non-interest generating business reduces the volumes of traditional loan business, which further proceeds a decrease in NIM of Chinese commercial banks.

In terms of the industry-specific determinants of bank profitability, in particular, the impacts of competition in different banking markets on bank profitability, the results show that higher levels of competition in loan market lead to higher ROA of Chinese commercial banks. This is attributed 
to the fact that a higher competitive loan market can be an indicator that there is a business boom in the economy, and different companies seeking the loans have lower default risk while the reduction in the cost of monitoring the loans leads to an increase in bank profitability. In comparison, the findings suggest that a higher competitive deposit market leads to a decline in bank profitability (ROA and NIM). This can be mainly explained by the fact that in a higher competitive deposit market, banks will try to increase the deposit interest rate, the resulted increase in the interest expenses leads to a decline in NIM. Furthermore, more effort and resources will be given by the bank to attract more deposit in the market, the resulted increase in the cost leads to a decline in ROA.

Banking sector development is found to be significantly and positively related to bank profitability (ROA). This can be explained by the fact that in a higher developed banking market, there will be a higher volume of demand for banking products (Tan and Floros, 2012a). This result indicates that there will be a significant increase in the demand of non-interest generating business in a higher developed banking market, which proceeds a significant increase in ROA but not NIM. The stock market development is found to be significantly and negatively related to ROA and NIM of Chinese commercial banks, indicating that Chinese commercial banks have lower profitability in a higher developed stock market. In a higher developed banking market, rather than investing the money in purchasing the non-interest generating products, the investors are more likely to invest the money in the stock market, which leads to a decline in ROA. Furthermore, for different companies, they will also go to the stock market rather than the banks to raise funds for their operation under the environment of higher developed stock market, this will proceed a decline in the volumes of loan granted by the banks and further result in a decrease in NIM of Chinese commercial banks. 
Finally, with regard to the macroeconomic determinants of bank profitability, the findings suggest that Chinese commercial banks have higher profitability in terms of ROA and NIM in a higher inflationary environment. The Higher inflationary environment is associated with higher loan interest rate, which will increase the bank profitability (Tan and Floros, 2012a). In theory, this result indicates that Chinese commercial banks have the ability to anticipate the interest rate and adjust the interest rate accordingly (Perry, 1992). Finally, the results suggest that in a higher economic growth period, Chinese commercial banks have higher NIM. This is in line with the findings of Demirguc-Kunt and Huizinga (1999) and can be explained by the fact that the demand for lending increases during cyclical upswings.

<<Table 7---about here >>

In order to check the robustness of the results, we estimate the impact of competition on bank profitability by using just one specific competition indicator for a specific banking market in the model. To be more specific, Table 8 , Table 9 and Table 10 test the impact of competition in the loan market, deposit market and non-interest market on bank profitability while controlling for other bank profitability determinants. We confirm some of the findings reported from Table 7 as follows: 1) bank profitability in terms of ROA and NIM is significantly and positively affected by the past year's profitability; 2) liquidity is significantly and positively related to the profitability of Chinese commercial banks; 3) large Chinese commercial banks have lower levels of ROA and NIM; 4) Chinese commercial banks with higher levels of business diversification have higher levels of ROA but lower levels of NIM; 5) higher developed banking sector leads to higher levels of ROA of Chinese commercial banks; 6) higher developed stock market leads to lower levels of NIM; 7) Chinese commercial banks have higher levels of ROA and NIM during the periods of 
higher inflation; 8) during the periods of economic boom, Chinese commercial banks have higher levels of NIM; 9) Chinese commercial banks have higher levels of profitability in a lower competitive deposit market.

$$
\begin{aligned}
& \text { <<Table 8-about here>> } \\
& \text { <<Table 9---about here>> } \\
& \text { <<Table 10---about here>> }
\end{aligned}
$$

Not only for the whole sample but more importantly, we test the impacts of competition in different banking markets on bank profitability for each different ownership types. To be more specific, we test the impact of competition in the different markets on bank profitability for state-owned commercial banks, joint-stock commercial banks as well as city commercial banks, the results of which are reported in Table 11, Table 12, and Table 13, respectively. With regard to the stateowned commercial banks, Table 11 shows that the profitability in the current year is significantly affected by previous year's profitability and state-owned commercial banks with higher levels of liquidity have higher levels of ROA. In addition, the results report that state-owned commercial banks with higher levels of capital have lower levels of ROA. State-owned commercial banks with higher levels of overhead cost are found to have higher levels of NIM. Finally, it is shown from the table that state-owned commercial banks engaging in more diversified business have lower NIM, while the coefficient of this variable is insignificant for ROA, indicating that for Chinese state-owned commercial banks, the traditional interest generating activities contribute more to the overall profitability compared to non-interest generating activities. It is further argued that in a higher competitive loan market, state-owned commercial banks have higher ROA and NIM while 
a higher competitive deposit market leads to lower profitability of Chinese state-owned commercial banks. Finally, it is found that Chinese state-owned commercial banks have higher profitability (NIM) in a higher inflationary environment.

In terms of the joint-stock commercial banks, which is reported from Table 12, the findings suggest that the NIM in the current year is significantly affected by the previous year's NIM, while the lagged ROA is not significant for joint-stock commercial banks. This finding to some extent reflects the fact that joint-stock commercial banks' profitability from non-interest generating business does not persistent, while in comparison, the profitability of traditional interest generating business tends to persist for joint-stock commercial banks. This can be explained by the fact that compared to state-owned commercial banks, joint-stock commercial banks have higher competition in terms of different types of non-interest generating business. Liquidity is found to be significantly and positively related to ROA of joint-stock commercial banks. The results report that larger joint-stock commercial banks have higher levels of NIM, this is attributed to the fact that large joint-stock commercial banks engage in larger volumes of loan business, the resulted reduction in cost from economies of scale leads to higher NIM. Different from the state-owned commercial banks, the findings show that joint-stock commercial banks with higher levels of insolvency risk have higher NIM. This can be explained by the fact that during the time with lower levels of capital and lower levels of liquidity, joint-stock commercial banks have more incentive and take more effort to monitor the loan business, the reduction in the volume of non-performing loans leads to an improvement in NIM. Same as the results reported for state-owned commercial banks, joint-stock commercial banks with higher levels of overhead cost have higher NIM. Compared to state-owned commercial banks, it is found that joint-stock commercial banks engaging in more diversified business have higher profitability while the impact is negative for 
NIM. These results reflect the fact that compared to state-owned commercial banks, non-interest generating activities contribute more than the traditional interest generating business to the overall bank profitability. It is found that a higher competitive loan market leads to higher ROA and NIM of joint-stock commercial banks while joint-stock commercial banks have higher ROA in a lower competitive deposit market. We find that in a lower competitive non-interest income market, jointstock commercial banks have higher levels of NIM. This can be explained by the fact that for jointstock commercial banks, a lower competitive non-interest income market induces bank managers to put more effort in the loan business, and more importantly, more funds will be available and transferred from the non-interest income generating business to loan business, higher volumes of loan business engaged in by joint-stock commercial banks together with better risk monitoring and management leads to an improvement in NIM. Higher developed banking sector leads to a decline in NIM of joint-stock commercial banks. As argued previously, there will be a higher volume of demand for banking business when there is a higher developed banking sector, these results indicate that joint-stock commercial banks have less effort in monitoring the loan business, which leads to a decline in NIM. The results further show that the stock market development has a significant and negative impact on NIM of joint-stock commercial banks. Finally, it is found that both inflation and GDP growth rate have significant and positive impacts on NIM for joint-stock commercial banks.

Table 13 reports the results with regard to the impact of competition in different banking market on bank profitability for city commercial banks. The findings suggest that the profitability of city commercial banks in the current year is significantly and positively affected by previous year's profitability. The profitability of interest generating business (loan business) tends to be persisted to a larger extent compared to the overall bank profitability as reflected by the coefficients, this 
reflects the fact that there is stronger competition in the non-interest activities compared to loan business for city commercial banks. Liquidity is found to be significantly and positively related to NIM of city commercial banks. Bank size is found to be significantly and negatively related to NIM of city commercial banks, this can be explained by the fact that larger city commercial banks take more effort and resources to engage in non-interest generating activities, less amount of funds available for the traditional loan business reduces the banks' NIM. Overhead cost is found to be significantly and positively related to the profitability of city commercial banks, which is in line with the efficiency wage theory. It is further reported from the table that city commercial banks with more diversified business have higher ROA but lower NIM, this finding reflects the fact that non-interest generating activities contribute more to the overall profitability of city commercial banks.

With regard to the industry-specific and macroeconomic determinants of profitability, the results show that a higher competitive loan market leads to higher ROA of city commercial banks, while a higher competitive deposit market reduces the banks' ROA. The results further report that in a higher developed banking sector, ROA of city commercial banks increases but with no significant impact on NIM. We explain this finding by the fact that higher demand for banking services derived from higher developed banking sector focuses on non-interest generating products. Because individual investors as well as different companies are more likely to invest their funds or raise money from stock market rather than the banking market, the reduction in the volumes of traditional interest generating business as well as non-interest generating activities decreases the bank profitability, as reflected by the significant and negative coefficient of stock market development. Same as the findings reported previously, inflation is found to be significantly and positively related to the profitability of city commercial banks. Finally, GDP is found to be 
significantly and positively related to NIM of city commercial banks, but significantly and negatively related to ROA. This finding can be explained by the fact that during the periods of economic boom, city commercial banks mainly concentrate on traditional interest-generating business, as discussed previously, non-interest generating activity contributes more to the overall profitability of city commercial banks, and the reduction in the volumes of non-interest generating business reduces the overall profitability of city commercial banks.

<<Table 11---about here >>

$<<$ Table 12---about here >>

$<<$ Table 13-about here >>

\section{Conclusion}

This study uses a sample of Chinese commercial banks (state-owned commercial banks, jointstock commercial banks, and city commercial banks) over the period 2003-2013 to test the impact of competition in different banking markets on bank profitability. Three different banking markets are analyzed which include the deposit market, loan market as well as the non-interest income market. This paper contributes to the empirical banking literature, in particular, fills in the gap of Tan (2017) by investigating the impacts of competition in different banking markets on profitability of three different ownership types of Chinese commercial banks and also stability inefficiency rather than the traditional Z-score is used to measure the insolvency risk in the Chinese banking industry, which is supposed to provide more accurate results. 
The findings suggest that for the whole bank sample being examined, the profitability of Chinese commercial banks tend to persist, although the extent is not very large. In other words, the profitability of Chinese commercial banks in the current year is significantly affected by the previous year's profitability. The results further suggest that Chinese commercial banks with higher levels of liquidity have higher levels of profitability. It is found that bank size has a significant and negative impact on profitability of Chinese commercial banks, and Chinese commercial banks with more diversified business have levels of ROA but lower levels of NIM. Higher developed banking sector is found to increase the banks' ROA while higher developed stock market has a significant and negative impact on NIM of Chinese commercial banks. The findings show that bank profitability in China is significantly and positively affected by inflation and GDP growth rate. Finally, a higher competitive deposit market leads to lower profitability of Chinese commercial banks.

With regard to the impact of competition on profitability for different ownership types of commercial banks, the results suggest that a higher competitive loan market leads to higher profitability of all these three types of banks while the impact of deposit market competition is significant and negative. The difference or special characteristics with regard to the determinants of profitability among these three different types of banks can be summarized as follows: 1) stateowned commercial banks with higher levels of capital have lower levels of profitability; 2) insolvency risk has a significant and positive impact on profitability for joint-stock commercial banks; 3) banking sector development has no impact on state-owned commercial banks, while different impacts have been exhibited for joint-stock commercial banks and city commercial banks; 4) stock market development has a significant impact on the profitability of joint-stock and city 
commercial banks, while the impact is insignificant for state-owned commercial banks; 5) higher levels of GDP growth rate lead to higher NIM but lower ROA of city commercial banks.

The results of the current paper provides important implications to Chinese government as well as banking regulatory authorities to make relevant policies to reform the banking sector and further improve the bank performance as follows: 1) Chinese commercial banks should be required to hold higher levels of liquidity; 2) relevant policy should be established and implemented to attract people with higher levels of professional knowledge and experience through higher salaries and also the staff should be better and more motivated through bonus to improve their productivity; 3 ) Chinese commercial banks should further explore the business areas in terms of non-interest generating activities; 4) relevant monetary policy should be implemented to increase the competition in the loan market while better regulation of deposit market is needed to reduce its competition; 5) relevant policy should be introduced to balance the inflation and bank profitability. More specifically, with regard to different ownerships of Chinese commercial banks, the following policies can be made: 1) state-owned commercial banks can adjust the capital levels in a more appropriate way, i.e. reduce the capital level to a certain extent; 2) liquidity and capital levels of joint-stock commercial banks can be reduced to a certain extent to balance the increase in the level of risk and the increase in the level of profitability.

The current paper suffers from a number of limitations: 1) although the current study uses a more advance method (i.e Boone indicator) to examine the competitive conditions in different banking markets in China and also use different bank samples as well as separate boone indicator in a specific market to check the accuracy of the results, single competition measurement (i.e only use Boone indicator) does not provide a very robustness analysis; 2) the current study use a sample of 
Chinese commercial banks with three different ownership types (state-owned banks, joint-stock banks and city banks) and does not consider other types of commercial banks in China, for example, foreign banks and private banks, which are also very important component in the Chinese banking industry. Therefore, in the future, the current study can be extended in the following ways: 1) an alternative competition indicator (i.e. Hirfindahl-hirschman index) can be used to estimate the competitive conditions in different banking markets in China and further test the impact of this on bank profitability in China; 2) foreign banks as well as private banks can be included in the analysis to see whether the impact of competition on profitability for these two types of banks is similar to or different from the ones for state-owned, joint-stock and city banks. 


\section{References:}

Ahamed, M. M. 2017. Asset quality, non-interest income, and bank profitability: Evidence from Indian Banks. Economic Modelling, vol. 63, 1-14.

Athanasoglou, P.P., Brissimis, S.N. and Delis, M.D. 2008. Bank-Specific, Industry-Specific and Macroeconomic Determinants of Bank Profitability. Journal of International Financial Markets, Institutions and Money, vol. 18, no. 2, 121-136.

Arellano, M., and Bover, O. 1995. Another look at the instrumental variable estimation of errorcomponents models. Journal of Econometrics, vol. 68, no. 1, 29-51.

Berger, A.N. 1995a. The Profit-Structure Relationship in Banking-Test of Market-Power and Efficient-Structure Hypotheses. Journal of Money, Credit and Banking, vol. 27, no. 2, 404-431.

Berger, A. N. 1995b. The relationship between capital and earnings in banking. Journal of Money, Credit and Banking, vol. 27, no. 2, 432-456.

Bond, S. 2002. Dynamic panel data models: a guide to micro data methods and practice. Portuguese Economic Journal, vol. 1, no. 2. 141-162.

Boone, J. 2008. A new way to measure competition. The Economic Journal, vol. 118, no. 531, 1245-1261.

Bourke, P. 1989. Concentration and other determinants of bank profitability in Europe, North America and Australia. Journal of Banking and Finance, vol. 13, no. 1, 65-79. 
Demirguc-Kunt, A. and Huizinga, H. 1999. Determinants of commercial bank interest margins and profitability: some international evidence. World Bank Economic Review, vol. 13, no. 2, 379408.

Demsetz, H. 1973. Industry structure, market rivalry and public policy. Journal of Law and Economics, vol. 16, no. 1, 1-19.

Dietrich, A. and Wanzenried, G. 2011.Determinants of bank profitability before and during the crisis: evidence from Switzerland. Journal of International Financial Markets, Institutions and Money, vol. 21, no. 3, 307-327.

Garcia, M.T.M. and Guerreiro, J.P.S.M. 2016. Internal and external determinants of banks' profitability: The Portuguese case. Journal of Economic Studies, vol. 43, no. 1, 90-117.

Garcia-Herrero, A., Gavila, S. and Santabarbara, D. 2009. What explains the low profitability of Chinese banks? Journal of Banking and Finance, vol. 33, no. 11, 2080-2092.

Goddard, J. A., Molyneux, P. M. and Wilson, J.O.S. 2001. European banking: efficiency, technology and growth, Chichester, Wiley.

Goddard, J., Molyneux, P. and Wilson, J. O. S. 2004a. Dynamic of growth and profitability in banking. Journal of Money, Credit and Banking, vol. 36, no. 6, 1069-1090.

Goddard, J., Molyneux, P. and Wilson, J. O. S. 2004b. The profitability of European banks: a cross-sectional and dynamic panel analysis. The Manchester School, vol. 72, no. 3, 363-381. 
Goddard, J., Molyneux, P., Liu, H. and Wilson, J.O.S. 2013. Do bank profits converge? European Financial Management, vol. 19, no. 2, 345-365.

Goldberg, L. G. and Rai, A. 1996. The Structure-Performance Relationship for European Banking. Journal of Banking and Finance, vol. 20, no. 4, 617-645.

Hasan, I. and Morton, K. 2003. Development and efficiency of the banking sector in a transitional economy: Hungarian experience. Journal of Banking and Finance, vol. 27, no. 12, 2249-2271.

Hoffmann, P. S. 2011. Determinants of the profitability of the US Banking Industry. International Journal of Business and Social Science, vol. 2, no. 22, 255-269.

Kutan, A. M., Ozsoz, E. and Rengifo, E. W. 2012. Cross-sectional determinants of bank performance under deposit dollarization in Emerging markets. Emerging Markets Review, vol. 13, no. $4,478-492$.

Lee, C. and Hsieh, M. 2013. The impact of bank capital on profitability and risk in Asian banking. Journal of International Money and Finance, vol. 32, 251-281.

Maudos, J. and Fenandez de Guevara, J. 2004. Factors explaining the interest margin in the banking sectors of the European Union. Journal of Banking and Finance, vol. 28, no. 9, 22592281.

Mirzaei, A., Moore, T. and Liu, G. 2013. Does market structure matter on banks' p0rofitability and stability? Emerging vs. advanced economies. Journal of Banking and Finance, vol. 37, no. 8, 2920-2937. 
Molyneux, P. and Thornton, J. 1992. Determinants of European bank profitability: A Note.

Journal of Banking and Finance, vol. 16, no. 6, 1173-1178.

Perry, P. 1992. Do banks gain or lose from inflation? Journal of Retail Banking, vol. 14, no. 2, 2530.

Rhoades, S. A. 1985. Market share as a source of market power: Implications and some evidence. Journal of Economics and Business, vol. 37, no. 4, 343-363.

Shih, V., Zhang, Q. and Liu, M. 2007. Comparing the performance of Chinese banks: a principle component approach. China Economic Review, vol. 18, no. 1, 15-34.

Smirlock, M. 1985. Evidence on the (non) relationship between concentration and profitability in banking. Journal of Money, Credit, and Banking, vol. 17, no. 1, 69-83.

Staikouras, C. and Wood, G. 2004. The determinants of bank profitability in Europe. International Business and Economic Research Journal, vol. 3, no. 6, 57-68.

Sufian, S. and Chong, R. R. 2008. Determinants of Bank Profitability in a Developing Economy: empirical evidence from Philippines. Asian Academy of management Journal of Accounting and Finance, vol. 4, no. 2, 91-112.

Sufian, F. 2009. Determinants of Bank profitability in a Developing Economy: Empirical evidence from the China Banking Sector. Journal of Asia-Pacific Business, vol. 10, no. 4, 201307. 
Sufian, F. and Habibullah, M. S. 2009. Bank specific and macroeconomic determinants of bank profitability: Empirical evidence from the China Banking Sector. Frontier of Economics in China, vol. 4, no. 2, 274-291.

Tabak, B. M., Fazio, D. M. and Cajueiro, D. O. 2012. The relationship between banking market competition and risk-taking: Do bank size and capitalization matter? Journal of Banking and Finance, vol. 36, no. 12, 3366-3381.

Tan, Y. and Floros, C. 2012a. Bank profitability and inflation: the case of China. Journal of Economic Studies, vol. 39, no. 6, 675-696.

Tan, Y. and Floros, C. 2012b. Bank profitability and GPD growth in China: a note. Journal of Chinese Economics and Business Studies, vol. 10, no. 3, 267-273.

Tan, Y. and Floros, C. 2012c. Stock market volatility and bank performance in China. Studies in Economics and Finance, vol. 29, no. 3, 211-228.

Tan, Y. 2016. The impacts of risk and competition on bank profitability in China. Journal of International Financial Markets, Institutions and Money, vol. 40, 85-110.

Tan, Y. and Floros, C. 2014. Risk, profitability and competition: evidence from the Chinese banking. Journal of Developing Areas, vol. 48, no. 3, 303-319.

Tan, Y. 2017. The impacts of competition and shadow banking on profitability: Evidence from the Chinese banking industry. The North American Journal of Economics and Finance, vol. 42, $89-106$. 
Tregenna, F. 2009. The fat years: the structure and profitability of the US banking sector in the pre-crisis period. Cambridge Journal of Economics, vol. 33, no. 4, 609-632.

Trujillo-Ponce, A. 2012. What determines the profitability of banks? Evidence from Spain. Accounting and Finance, vol. 53, no. 2, 561-586.

Yao, H., Haris, M., and Tariq, G. 2018. Profitability determinants of financial institutions:

Evidence from Banks in Pakistan. International Journal of Financial Studies, vol. 6, 53. 
Table 1 Summary of the assets of SOCBs, JSCBs, CCBs and total banking institutions in China over the period $2003-2013$

\begin{tabular}{|c|c|c|c|c|c|c|c|c|c|c|c|}
\hline & 2003 & 2004 & 2005 & 2006 & 2007 & 2008 & 2009 & 2010 & 2011 & 2012 & 2013 \\
\hline SOCBs & $\begin{array}{l}160512 \\
(58.03 \%)\end{array}$ & $\begin{array}{l}179817 \\
(56.9 \%)\end{array}$ & $\begin{array}{l}210050 \\
(56.1 \%)\end{array}$ & $\begin{array}{l}242364 \\
(55.2 \%)\end{array}$ & $\begin{array}{l}285000 \\
(53.7 \%)\end{array}$ & $\begin{array}{l}325751 \\
(51.59 \%)\end{array}$ & $\begin{array}{l}407998 \\
(51.31 \%)\end{array}$ & $\begin{array}{l}468943 \\
(49.2 \%)\end{array}$ & $\begin{array}{l}536336 \\
(47.34 \%)\end{array}$ & $\begin{array}{l}600401 \\
(52.84 \%)\end{array}$ & $\begin{array}{l}656005 \\
(43.34 \%)\end{array}$ \\
\hline JSCBs & $\begin{array}{l}29599 \\
(10.7 \%)\end{array}$ & $\begin{array}{l}36476 \\
(11.5 \%)\end{array}$ & $\begin{array}{l}44655 \\
(11.92 \%)\end{array}$ & $\begin{array}{l}54446 \\
(12.4 \%)\end{array}$ & $\begin{array}{l}72742 \\
(13.69 \%)\end{array}$ & $\begin{array}{l}88337 \\
(13.99 \%)\end{array}$ & $\begin{array}{l}118181 \\
(14.86 \%)\end{array}$ & $\begin{array}{l}149037 \\
(15.64 \%)\end{array}$ & $\begin{array}{l}183794 \\
(16.22 \%)\end{array}$ & $\begin{array}{l}235271 \\
(20.71 \%)\end{array}$ & $\begin{array}{l}269361 \\
(17.8 \%)\end{array}$ \\
\hline CCBs & $\begin{array}{l}14622 \\
(5.3 \%)\end{array}$ & $\begin{array}{l}17056 \\
(5.4 \%)\end{array}$ & $\begin{array}{l}20367 \\
(5.44 \%)\end{array}$ & $\begin{array}{l}25938 \\
(5.9 \%)\end{array}$ & $\begin{array}{l}33405 \\
(6.29 \%)\end{array}$ & $\begin{array}{l}41320 \\
(6.54 \%)\end{array}$ & $\begin{array}{l}56800 \\
(7.14 \%)\end{array}$ & $\begin{array}{l}78526 \\
(8.24 \%)\end{array}$ & $\begin{array}{l}99845 \\
(8.81 \%)\end{array}$ & $\begin{array}{l}123469 \\
(10.87 \%)\end{array}$ & $\begin{array}{l}151778 \\
(10.03 \%)\end{array}$ \\
\hline $\begin{array}{l}\text { Banking } \\
\text { institutions }\end{array}$ & 276584 & 315990 & 374697 & 439500 & 531160 & 631515 & 795146 & 953053 & 1132873 & 1136224 & 1513547 \\
\hline
\end{tabular}




\section{Table 2}

\begin{tabular}{|c|c|c|c|c|}
\hline References & $\begin{array}{l}\text { Banking sector } \\
\text { investigated }\end{array}$ & Data period & Methodology & Empirical results \\
\hline Smirlock (1985) & $\begin{array}{l}\text { US banking } \\
\text { industry }\end{array}$ & 1973-1978 & $\begin{array}{l}\text { Ordinary least } \\
\text { square estimator }\end{array}$ & $\begin{array}{l}\text { Size is significantly and negatively related to bank } \\
\text { profitability }\end{array}$ \\
\hline Rhoades (1985) & $\begin{array}{l}\text { US banking } \\
\text { industry }\end{array}$ & 1969-1978 & $\begin{array}{l}\text { Ordinary least } \\
\text { square estimator }\end{array}$ & $\begin{array}{l}\text { There is a significant and negative impact of risk on bank } \\
\text { profitability }\end{array}$ \\
\hline $\begin{array}{l}\text { Molyneux and } \\
\text { Thornton (1992) }\end{array}$ & $\begin{array}{l}\text { European } \\
\text { banking } \\
\text { industry }\end{array}$ & 1986-1989 & $\begin{array}{l}\text { Ordinary least } \\
\text { square estimator }\end{array}$ & $\begin{array}{l}\text { Liquidity is significantly and negative related to bank } \\
\text { profitability }\end{array}$ \\
\hline Berger (1995a) & $\begin{array}{l}\text { US banking } \\
\text { industry }\end{array}$ & Ten years of $1980 \mathrm{~s}$ & $\begin{array}{l}\text { Ordinary least } \\
\text { square estimator }\end{array}$ & $\begin{array}{l}\text { Banks with larger market share and differentiate product } \\
\text { have higher profitability }\end{array}$ \\
\hline Berger (1995b) & $\begin{array}{l}\text { US banking } \\
\text { industry }\end{array}$ & 1983-1989 & $\begin{array}{l}\text { Grainger Causality } \\
\text { test }\end{array}$ & $\begin{array}{l}\text { There is a significant and positive relationship between } \\
\text { capitalization and bank profitability }\end{array}$ \\
\hline $\begin{array}{l}\text { Goddard et al. } \\
\text { (2001) }\end{array}$ & $\begin{array}{l}\text { European } \\
\text { banking } \\
\text { industry }\end{array}$ & 1989-1996 & $\begin{array}{l}\text { Ordinary least } \\
\text { square estimator }\end{array}$ & $\begin{array}{l}\text { Scale economies and productive efficiency are positively } \\
\text { related to profitability, while bank size has negative } \\
\text { impact on profitability. }\end{array}$ \\
\hline $\begin{array}{l}\text { Staikouras and } \\
\text { Wood (2004) }\end{array}$ & $\begin{array}{l}\text { European } \\
\text { banking } \\
\text { industry }\end{array}$ & 1994-1998 & $\begin{array}{l}\text { Fixed } \\
\text { estimator }\end{array}$ & There is a negative impact of risk on bank profitability \\
\hline
\end{tabular}




\begin{tabular}{|c|c|c|c|c|}
\hline $\begin{array}{l}\text { Goddard et al. } \\
(2004 a)\end{array}$ & $\begin{array}{l}\text { European } \\
\text { banking } \\
\text { industry }\end{array}$ & 1992-1998 & GMM & $\begin{array}{l}\text { There is a positive impact of diversification on bank } \\
\text { profitability }\end{array}$ \\
\hline $\begin{array}{l}\text { Goddard et al. } \\
(2004 b)\end{array}$ & $\begin{array}{l}\text { European } \\
\text { banking } \\
\text { industry }\end{array}$ & $1992-1998$ & OLS and GMM & $\begin{array}{l}\text { Capital-asset ratio has a significant and positive impact } \\
\text { on bank profitability }\end{array}$ \\
\hline $\begin{array}{l}\text { Sufian and Chong } \\
(2008)\end{array}$ & $\begin{array}{l}\text { Philippine } \\
\text { banking } \\
\text { industry }\end{array}$ & $1990-2005$ & $\begin{array}{l}\text { Fixed effect } \\
\text { estimator }\end{array}$ & $\begin{array}{l}\text { Risk is significantly and negatively related to bank } \\
\text { profitability }\end{array}$ \\
\hline $\begin{array}{l}\text { Athanasoglou et } \\
\text { al. (2008) }\end{array}$ & $\begin{array}{l}\text { Greek banking } \\
\text { industry }\end{array}$ & $1985-2001$ & GMM & $\begin{array}{l}\text { There is no evidence in support of structure-conduct- } \\
\text { performance paradigm in Greek banking industry }\end{array}$ \\
\hline Tregenna (2009) & $\begin{array}{l}\text { US banking } \\
\text { industry }\end{array}$ & 1994-2005 & OLS and GMM & Bank concentration increases bank profitability \\
\hline $\begin{array}{c}\text { Dietrich and } \\
\text { Wanzenried } \\
\text { (2011) }\end{array}$ & $\begin{array}{l}\text { Switzerland } \\
\text { banking } \\
\text { industry }\end{array}$ & 1999-2009 & GMM & $\begin{array}{l}\text { Banks with more diversified activities have higher } \\
\text { profitability }\end{array}$ \\
\hline Hoffmann (2011) & $\begin{array}{l}\text { US banking } \\
\text { industry }\end{array}$ & $1995-2007$ & GMM & $\begin{array}{l}\text { There is a significant impact of capital ratio on bank } \\
\text { profitability }\end{array}$ \\
\hline $\begin{array}{l}\text { Kutan et al. } \\
\text { (2012) }\end{array}$ & $\begin{array}{l}\text { A sample of } \\
\text { banks from } 36 \\
\text { dollarized } \\
\text { banking system }\end{array}$ & $1991-2006$ & $\begin{array}{l}\text { Fixed effect and } \\
\text { GMM }\end{array}$ & $\begin{array}{l}\text { Credit risk has a significant and negative impact on bank } \\
\text { profitability }\end{array}$ \\
\hline $\begin{array}{l}\text { Goddard et al. } \\
\text { (2013) }\end{array}$ & $\begin{array}{l}\text { European } \\
\text { banking } \\
\text { industry }\end{array}$ & $1992-2007$ & GMM & $\begin{array}{l}\text { Profitability is higher for banks that are efficient and } \\
\text { diversified, while low for those that are higher capitalized }\end{array}$ \\
\hline
\end{tabular}




\begin{tabular}{|c|c|c|c|c|c|}
\hline $\begin{array}{l}\text { Mirzaei et al. } \\
\quad(2013)\end{array}$ & $\begin{array}{l}\text { A sample of } \\
\text { banks from } \\
\text { advanced and } \\
\text { emerging } \\
\text { economies }\end{array}$ & $1999-2008$ & $\begin{array}{l}\text { Fixed } \\
\text { estimation }\end{array}$ & effect & $\begin{array}{l}\text { Lower competitive condition leads to higher bank } \\
\text { profitability for advanced economies, however, this is not } \\
\text { the case for emerging economies. }\end{array}$ \\
\hline $\begin{array}{l}\text { Trujillo-Ponce } \\
\text { (2013) }\end{array}$ & $\begin{array}{l}\text { Spain banking } \\
\text { industry }\end{array}$ & 1999-2009 & GMM & & $\begin{array}{l}\text { Liquidity, capital and credit risk are significantly related } \\
\text { to bank profitability }\end{array}$ \\
\hline $\begin{array}{l}\text { Lee and Hsieh } \\
\text { (2014) }\end{array}$ & $\begin{array}{l}\text { A sample of } \\
\text { commercial } \\
\text { banks from } \\
\text { Asian } \\
\text { Economies }\end{array}$ & 1994-2008 & GMM & & Capital has a significant impact on bank profitability. \\
\hline $\begin{array}{c}\text { Garcia and } \\
\text { Guerreiro (2016) }\end{array}$ & $\begin{array}{l}\text { Portuguese } \\
\text { banking system }\end{array}$ & $2002-2011$ & $\begin{array}{l}\text { Fixed } \\
\text { estimator }\end{array}$ & effect & $\begin{array}{l}\text { Capital and credit risk has a significant and negative } \\
\text { impact on bank profitability }\end{array}$ \\
\hline
\end{tabular}


Table 3 Description of the variables and their impact on bank profitability

\begin{tabular}{|c|c|c|c|}
\hline Variables & Measurement & Expected effect & Source \\
\hline \multicolumn{4}{|l|}{$\begin{array}{l}\text { Profitability } \\
\text { indicators }\end{array}$} \\
\hline ROA & $\begin{array}{l}\text { Net income/total } \\
\text { assets }\end{array}$ & & Bankscope \\
\hline NIM & $\begin{array}{l}\text { Net interest } \\
\text { income/earning } \\
\text { assets }\end{array}$ & & Bankscope \\
\hline \multicolumn{4}{|l|}{$\begin{array}{l}\text { Bank-specific } \\
\text { variables }\end{array}$} \\
\hline Credit risk & $\begin{array}{l}\text { impaired } \\
\text { loans/gross loans }\end{array}$ & - & Bankscope \\
\hline Liquidity & $\begin{array}{l}\text { liquid assets/total } \\
\text { assets }\end{array}$ & $?$ & Bankscope \\
\hline Capital & $\begin{array}{l}\text { Total regulatory } \\
\text { capital ratio }\end{array}$ & $?$ & Bankscope \\
\hline Insolvency risk & $\begin{array}{l}\text { stability } \\
\text { inefficiency }\end{array}$ & - & Bankscope \\
\hline bank size & $\begin{array}{l}\text { natural logarithm of } \\
\text { total assets }\end{array}$ & + & Bankscope \\
\hline Bank diversification & $\begin{array}{l}\text { Non-interest } \\
\text { income/gross } \\
\text { revenue }\end{array}$ & + & Bankscope \\
\hline Overhead cost & $\begin{array}{l}\text { Overhead } \\
\text { expenses/total } \\
\text { assets }\end{array}$ & $?$ & Banksocpe \\
\hline \multicolumn{4}{|l|}{$\begin{array}{l}\text { Industry-specific } \\
\text { variables }\end{array}$} \\
\hline Bank competition & Boone indicator & + & \\
\hline $\begin{array}{l}\text { Banking sector } \\
\text { development }\end{array}$ & $\begin{array}{l}\text { Banking sector } \\
\text { assets/GDP }\end{array}$ & + & $\begin{array}{l}\text { China Banking } \\
\text { Regulatory } \\
\text { Commission }\end{array}$ \\
\hline $\begin{array}{l}\text { Stock market } \\
\text { development }\end{array}$ & $\begin{array}{l}\text { Market } \\
\text { capitalization of } \\
\text { listed } \\
\text { companies/GDP }\end{array}$ & + & World Bank \\
\hline \multicolumn{4}{|l|}{$\begin{array}{l}\text { Macroeconomic } \\
\text { variables }\end{array}$} \\
\hline Inflation & $\begin{array}{l}\text { Annual inflation } \\
\text { rate }\end{array}$ & $?$ & World Bank \\
\hline GDP growth & $\begin{array}{l}\text { Annual GDP } \\
\text { growth rate }\end{array}$ & - & World Bank \\
\hline
\end{tabular}


Table 4 Descriptive statistics of all variables considered in this study

\begin{tabular}{|l|l|l|l|l|l|}
\hline Variables & Observations & Mean & S.D & Min & Max \\
\hline Credit risk & 632 & 2.78 & 4.48 & 0 & 41.86 \\
\hline Liquidity & 777 & 0.27 & 0.11 & 0.02 & 0.67 \\
\hline Capital & 637 & 11.91 & 4.7 & 0.62 & 62.62 \\
\hline $\begin{array}{l}\text { Insolvency } \\
\text { risk }\end{array}$ & 1100 & 0.33 & 0.21 & 0.025 & 0.789 \\
\hline Bank size & 843 & 4.9 & 0.992 & 0.71 & 8.51 \\
\hline $\begin{array}{l}\text { Bank } \\
\text { diversification }\end{array}$ & 828 & 13.98 & 13.31 & -12.94 & 79.4 \\
\hline \begin{tabular}{l} 
Overhead cost \\
\hline $\begin{array}{l}\text { Banking } \\
\text { sector } \\
\text { development }\end{array}$
\end{tabular}$\quad 788$ & 0.01 & 0.004 & 0.002 & 0.04 \\
\hline $\begin{array}{l}\text { Stock market } \\
\text { development }\end{array}$ & 11027 & 2.22 & 0.24 & 1.98 & 2.66 \\
\hline Inflation & 1227 & 71.2 & 43.49 & 31.9 & 184.1 \\
\hline $\begin{array}{l}\text { GDP growth } \\
\text { rate }\end{array}$ & 1199 & 10.19 & 1.87 & 7.7 & 14.2 \\
\hline
\end{tabular}


Table 5 Summary statistics

\begin{tabular}{|l|l|l|l|l|l|}
\hline Variables & Observations & Mean & S.D & Min & Max \\
\hline $\begin{array}{l}\text { Total cost } \\
\text { (interest and } \\
\text { expenses and } \\
\text { non-interest } \\
\text { expenses) }\end{array}$ & 777 & 3.35 & 0.97 & -0.79 & 6.86 \\
\hline $\begin{array}{l}\text { Price of } \\
\text { funds (the } \\
\text { ratio of } \\
\text { interest } \\
\text { expenses to } \\
\text { total } \\
\text { deposits) }\end{array}$ & 777 & 1.27 & 0.18 & 0.74 & 1.96 \\
\hline $\begin{array}{l}\text { Price of } \\
\text { capital (the } \\
\text { ratio of non- } \\
\text { interest to } \\
\text { expenses to } \\
\text { fixed assets) }\end{array}$ & 776 & 1.92 & 0.26 & 0.68 & 2.83 \\
\hline Total loans & 784 & 4.59 & 0.99 & 0.34 & 7.95 \\
\hline Securities & 782 & 4.21 & 1.04 & -0.41 & 7.87 \\
\hline $\begin{array}{l}\text { Non-interest } \\
\text { income }\end{array}$ & 767 & 2.34 & 1.1 & -2.4 & 5.81 \\
\hline $\begin{array}{l}\text { Total } \\
\text { deposits }\end{array}$ & 784 & 4.85 & 0.98 & 0.66 & 8.26 \\
\hline
\end{tabular}


Table 6a Descriptive statistics for profitability measures of Chinese banking industry

\begin{tabular}{|l|l|l|l|l|l|}
\hline & Observations & Mean & $\begin{array}{l}\text { Standard } \\
\text { deviation }\end{array}$ & Minimum & Maximum \\
\hline ROA & 808 & 0.0088 & 0.0066 & -0.04 & 0.106 \\
\hline NIM & 799 & 3.04 & 1.13 & 0.42 & 8.99 \\
\hline
\end{tabular}

Table 6b Descriptive statistics for profitability measures of state-owned commercial banks

\begin{tabular}{|l|l|l|l|l|l|}
\hline & Observations & Mean & $\begin{array}{l}\text { Standard } \\
\text { deviation }\end{array}$ & Minimum & Maximum \\
\hline ROA & 55 & 0.009 & 0.004 & 0.0002 & 0.014 \\
\hline NIM & 56 & 2.57 & 0.41 & 1.05 & 3.29 \\
\hline
\end{tabular}

Table 6c Descriptive statistics for profitability measures of joint-stock commercial banks

\begin{tabular}{|l|l|l|l|l|l|}
\hline & Observations & Mean & $\begin{array}{l}\text { Standard } \\
\text { deviation }\end{array}$ & Minimum & Maximum \\
\hline ROA & 127 & 0.006 & 0.006 & -0.04 & 0.0133 \\
\hline NIM & 131 & 2.43 & 0.477 & 0.68 & 3.42 \\
\hline
\end{tabular}

Table 6d Descriptive statistics for profitability measures of city commercial banks

\begin{tabular}{|l|l|l|l|l|l|}
\hline & Observations & Mean & $\begin{array}{l}\text { Standard } \\
\text { deviation }\end{array}$ & Minimum & Maximum \\
\hline ROA & 598 & 0.0093 & 0.007 & -0.005 & 0.106 \\
\hline NIM & 612 & 3.22 & 1.22 & 0.42 & 8.99 \\
\hline
\end{tabular}


Figure 1 The profitability of three different ownership types of Chinese commercial banks over the period 2003-2013
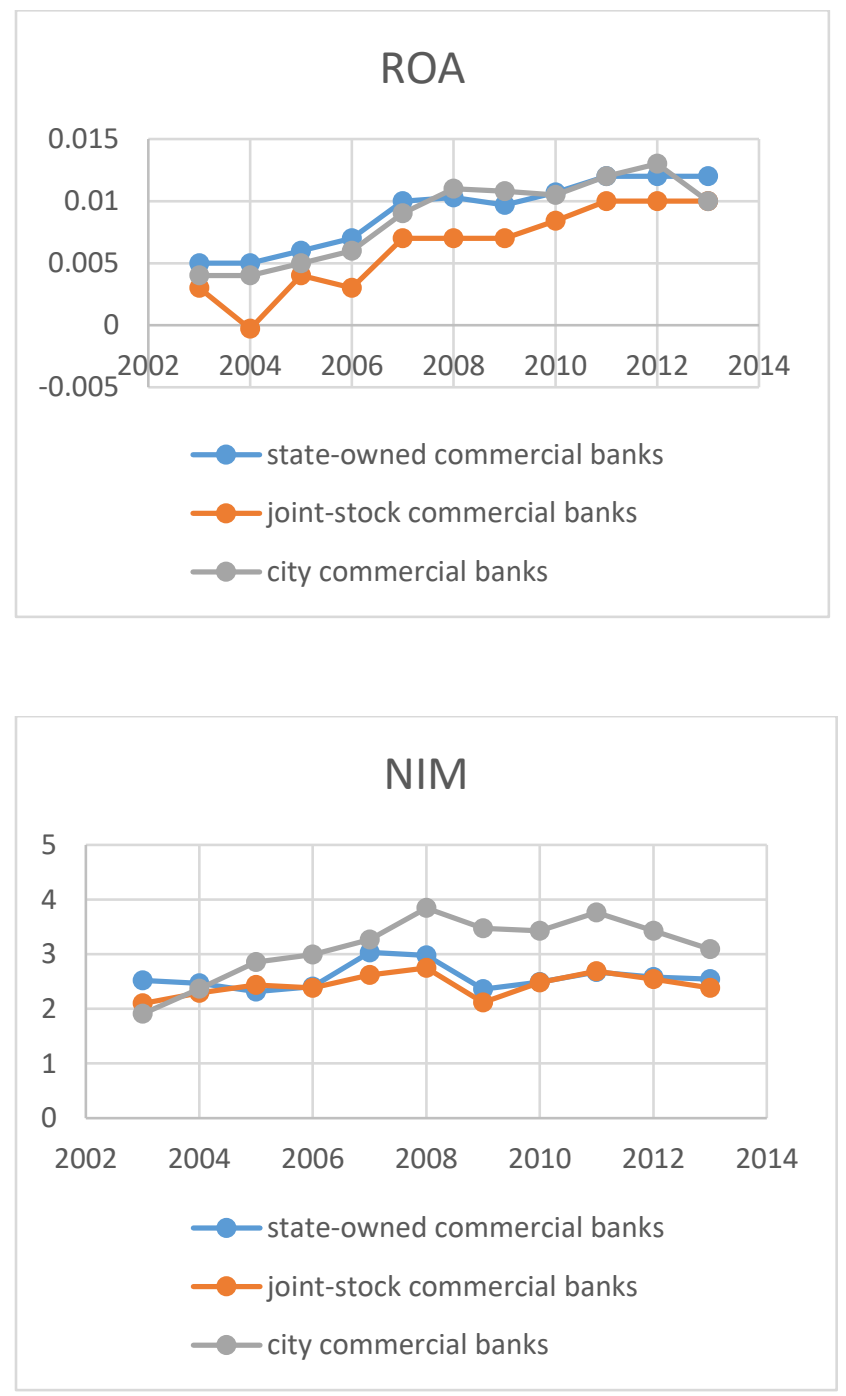
Figure 2 Competitive condition in different banking markets in China over 2003-2013

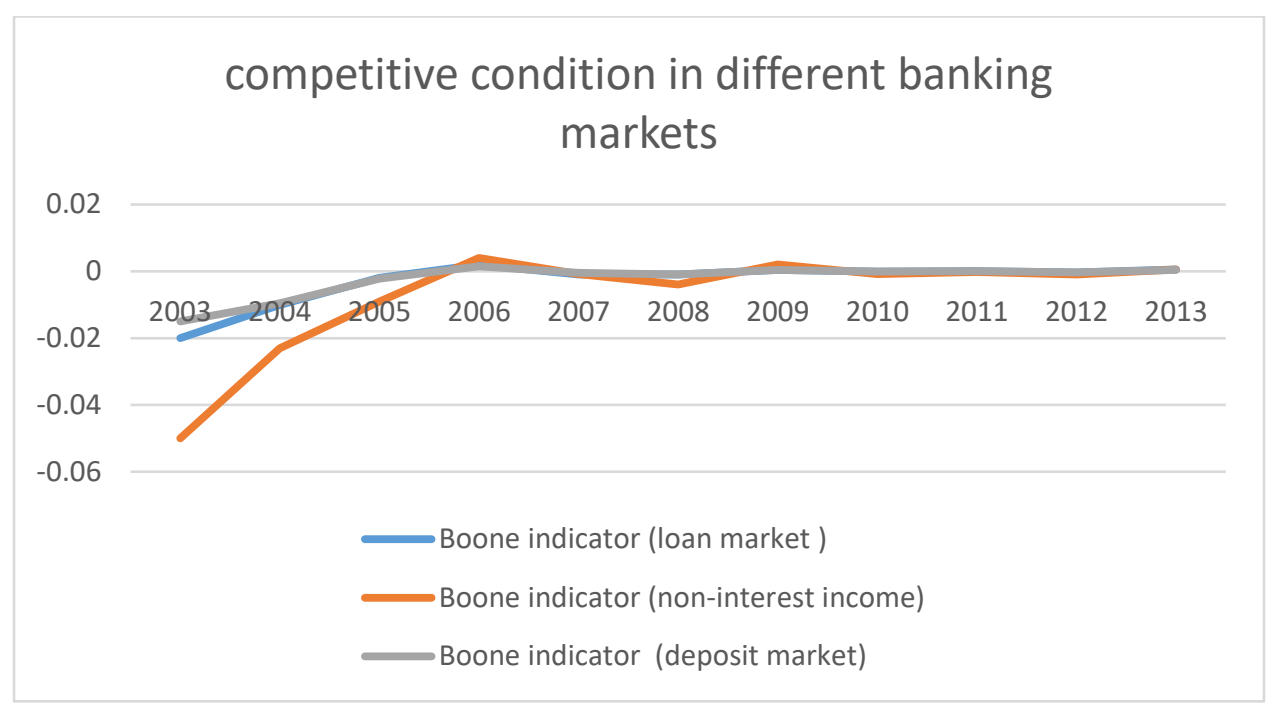


Figure 3 Insolvency risk (stability inefficiency) in the Chinese banking industry: 20032013

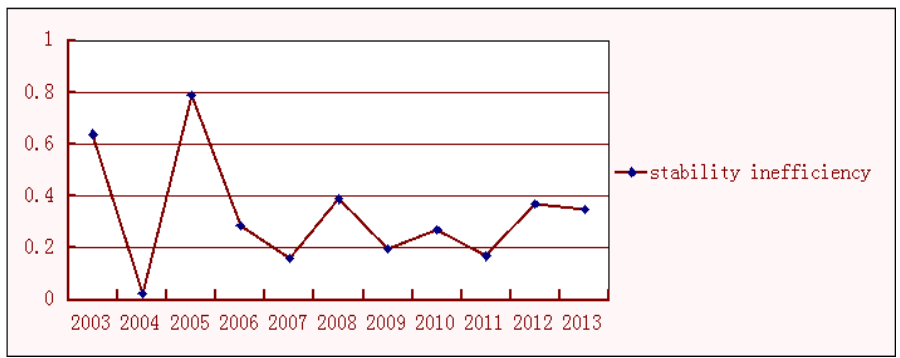


Table 7 Empirical results: The impact of competition on bank profitability (whole sample)

\begin{tabular}{|c|c|c|c|c|}
\hline & \multicolumn{2}{|l|}{ ROA } & \multicolumn{2}{|l|}{ NIM } \\
\hline & coefficient & t-statistic & Coefficient & t-statistic \\
\hline Lag of dependent variable & $0.08 * *$ & 2.53 & $0.36^{* * * *}$ & 9.34 \\
\hline \multicolumn{5}{|l|}{ Bank characteristics } \\
\hline Credit risk & -0.0001 & -1.40 & $0.09^{*}$ & 1.72 \\
\hline Liquidity & $0.0003^{* *}$ & 2.06 & $0.05 * * *$ & 3.57 \\
\hline Capital & $-0.005 * *$ & -2.24 & -0.92 & -0.68 \\
\hline Insolvency risk & -0.001 & -0.37 & -0.05 & -0.09 \\
\hline Bank size & $-0.0003 * *$ & -2.10 & $-0.13 * * *$ & -2.73 \\
\hline Overhead cost & $0.18 * * *$ & 3.05 & $136.76^{* * *}$ & 10.28 \\
\hline Bank diversification & $0.00003 * *$ & 2.14 & $-0.04 * * *$ & -3.35 \\
\hline \multicolumn{5}{|l|}{ Industry characteristics } \\
\hline Boone indicator (loan) & $-4.91 * * *$ & -4.19 & -365.23 & -1.48 \\
\hline Boone indicator (deposit) & $5.38 * * *$ & 3.63 & $310.61^{* * *}$ & 2.60 \\
\hline $\begin{array}{l}\text { Boone indicator (non- } \\
\text { interest income) }\end{array}$ & 0.1 & 0.19 & 75.4 & 0.80 \\
\hline $\begin{array}{l}\text { Banking sector } \\
\text { development }\end{array}$ & $0.005^{* * *}$ & 4.59 & 0.41 & 1.44 \\
\hline $\begin{array}{l}\text { Stock market } \\
\text { development }\end{array}$ & $\begin{array}{l}- \\
0.00003 * * \\
*\end{array}$ & -2.66 & $-0.006 * * *$ & -2.68 \\
\hline \multicolumn{5}{|l|}{ Macroeconomics } \\
\hline Inflation & $0.0004 * * *$ & 3.29 & $0.1 * * *$ & 4.47 \\
\hline GDP growth rate & -0.0001 & -0.88 & $0.06^{* * * *}$ & 2.64 \\
\hline F test & \multicolumn{2}{|l|}{$339.02 * * *$} & \multicolumn{2}{|l|}{$1275.24 * * *$} \\
\hline Sargan test & \multicolumn{2}{|l|}{57.73} & \multicolumn{2}{|l|}{30.95} \\
\hline $\mathrm{AR}(1)$ & -5.68 & 0.000 & -3.63 & 0.000 \\
\hline $\mathrm{AR}(2)$ & -1.01 & 0.312 & -1.16 & 0.248 \\
\hline No. of observations & \multicolumn{2}{|l|}{409} & \multicolumn{2}{|l|}{387} \\
\hline
\end{tabular}

$* * *$ and ${ }^{* * *}$ denote significance at $10 \%, 5 \%$ and $1 \%$ levels, respectively. 
Table 8 Empirical results: The impact of competition on bank profitability (loan market)

\begin{tabular}{|c|c|c|c|c|}
\hline & \multicolumn{2}{|l|}{ ROA } & \multicolumn{2}{|l|}{ NIM } \\
\hline & coefficient & t-statistic & Coefficient & t-statistic \\
\hline Lag of dependent variable & $0.07 * *$ & 2.29 & $0.36 * * *$ & 10.13 \\
\hline \multicolumn{5}{|l|}{ Bank characteristics } \\
\hline Credit risk & $-0.0002 * *$ & -2.06 & 0.05 & 1.15 \\
\hline Liquidity & $0.0004 * *$ & 2.52 & $0.05 * * *$ & 3.73 \\
\hline Capital & -0.003 & -1.62 & -0.23 & -0.20 \\
\hline Insolvency risk & $-0.003 * *$ & -2.27 & -0.26 & -1.41 \\
\hline Bank size & $-0.0004 * *$ & -2.46 & $-0.14 * * *$ & -3.10 \\
\hline Overhead cost & $0.13 * *$ & 2.18 & $134.87 * * *$ & 11.01 \\
\hline Bank diversification & $0.00004 * *$ & 2.23 & $-0.04 * * *$ & -3.66 \\
\hline \multicolumn{5}{|l|}{ Industry characteristics } \\
\hline Boone indicator & $0.19 *$ & 1.84 & $45.9 * *$ & 2.48 \\
\hline $\begin{array}{l}\text { Banking sector } \\
\text { development }\end{array}$ & $0.004 * * *$ & 4.78 & 0.37 & 1.52 \\
\hline $\begin{array}{l}\text { Stock market } \\
\text { development }\end{array}$ & $2.47 e-06$ & 0.46 & $-0.003 * * *$ & -3.28 \\
\hline \multicolumn{5}{|l|}{ Macroeconomics } \\
\hline Inflation & $0.0005 * * *$ & 5.66 & $0.07 * * *$ & 5.05 \\
\hline GDP growth rate & $-0.0003 * * *$ & -2.67 & $0.05 * *$ & 2.59 \\
\hline F test & \multicolumn{2}{|l|}{$341.7 * * *$} & \multicolumn{2}{|l|}{$1746.16^{* * *}$} \\
\hline Sargan test & \multicolumn{2}{|l|}{68.90} & \multicolumn{2}{|l|}{39.55} \\
\hline $\mathrm{AR}(1)$ & -5.95 & 0.000 & -3.56 & 0.000 \\
\hline $\operatorname{AR}(2)$ & -0.83 & 0.405 & -1.54 & 0.123 \\
\hline No. of observations & \multicolumn{2}{|l|}{409} & \multicolumn{2}{|l|}{387} \\
\hline
\end{tabular}

$*, * *$ and $* * *$ denote significance at $10 \%, 5 \%$ and $1 \%$ levels, respectively. 
Table 9 Empirical results: The impact of competition on bank profitability (deposit market)

\begin{tabular}{|c|c|c|c|c|}
\hline & \multicolumn{2}{|l|}{ ROA } & \multicolumn{2}{|l|}{ NIM } \\
\hline & coefficient & t-statistic & Coefficient & t-statistic \\
\hline Lag of dependent variable & $0.07 * *$ & 2.32 & $0.36 * * *$ & 9.95 \\
\hline \multicolumn{5}{|l|}{ Bank characteristics } \\
\hline Credit risk & $-0.0001 *$ & -1.96 & 0.06 & 1.28 \\
\hline Liquidity & $0.0003 * *$ & 2.43 & $0.05 * * *$ & 3.70 \\
\hline Capital & $-0.004 *$ & -1.67 & -0.34 & -0.29 \\
\hline Insolvency risk & $-0.003 * *$ & -2.36 & -0.31 & -1.59 \\
\hline Bank size & $-0.0004 * *$ & -2.40 & $-0.15 * * *$ & -2.99 \\
\hline Overhead cost & $0.13^{* *}$ & 2.28 & $135.61 * * *$ & 10.97 \\
\hline Bank diversification & $0.00004 * *$ & 2.22 & $-0.04 * * *$ & -3.61 \\
\hline \multicolumn{5}{|l|}{ Industry characteristics } \\
\hline Boone indicator & $0.25 * *$ & 2.24 & $65.12 * * *$ & 2.69 \\
\hline $\begin{array}{l}\text { Banking sector } \\
\text { development }\end{array}$ & $0.004 * * *$ & 4.87 & 0.39 & 1.57 \\
\hline $\begin{array}{l}\text { Stock market } \\
\text { development }\end{array}$ & $9.03 \mathrm{e}-07$ & 0.16 & $-0.003^{* * * *}$ & -3.63 \\
\hline \multicolumn{5}{|l|}{ Macroeconomics } \\
\hline Inflation & $0.0005^{* * *}$ & 5.83 & $0.08^{* * *}$ & 5.07 \\
\hline GDP growth rate & $-0.0003 * * *$ & -2.62 & $0.05^{* * *}$ & 2.53 \\
\hline F test & \multicolumn{2}{|l|}{$345.39 * * *$} & \multicolumn{2}{|l|}{$1690.50 * * *$} \\
\hline Sargan test & \multicolumn{2}{|l|}{68.09} & \multicolumn{2}{|l|}{37.73} \\
\hline $\mathrm{AR}(1)$ & -5.95 & 0.000 & -3.58 & 0.000 \\
\hline $\mathrm{AR}(2)$ & -0.82 & 0.409 & -1.46 & 0.145 \\
\hline No. of observations & \multicolumn{2}{|l|}{409} & \multicolumn{2}{|l|}{387} \\
\hline
\end{tabular}

$*, * *$ and $* * *$ denote significance at $10 \%, 5 \%$ and $1 \%$ levels, respectively. 
Table 10 Empirical results: The impact of competition on bank profitability (non-interest income market)

\begin{tabular}{|c|c|c|c|c|}
\hline & \multicolumn{2}{|l|}{ ROA } & \multicolumn{2}{|l|}{ NIM } \\
\hline & coefficient & t-statistic & Coefficient & t-statistic \\
\hline Lag of dependent variable & $0.08 * *$ & 2.29 & $0.36^{* * * *}$ & 10.08 \\
\hline \multicolumn{5}{|l|}{ Bank characteristics } \\
\hline Credit risk & $-0.0001 * *$ & -2.02 & 0.06 & 1.21 \\
\hline Liquidity & $0.0004 * *$ & 2.49 & $0.05 * * *$ & 3.75 \\
\hline Capital & -0.003 & -1.65 & -0.27 & -0.23 \\
\hline Insolvency risk & $-0.002 *$ & -1.93 & -0.14 & -0.83 \\
\hline Bank size & $-0.0004 * *$ & -2.41 & $-0.44 * * *$ & -3.08 \\
\hline Overhead cost & $0.13^{* *}$ & 2.24 & $134.51 * * *$ & 10.89 \\
\hline Bank diversification & $0.00004 * *$ & 2.22 & $-0.04 * * *$ & -3.61 \\
\hline \multicolumn{5}{|l|}{ Industry characteristics } \\
\hline Boone indicator & $0.096^{* *}$ & 2.11 & $20.29 * *$ & 2.49 \\
\hline $\begin{array}{l}\text { Banking sector } \\
\text { development }\end{array}$ & $0.004 * * *$ & 4.74 & 0.35 & 1.44 \\
\hline $\begin{array}{l}\text { Stock market } \\
\text { development }\end{array}$ & $5.18 \mathrm{e}-07$ & 0.09 & $-0.003 * * *$ & -3.64 \\
\hline \multicolumn{5}{|l|}{ Macroeconomics } \\
\hline Inflation & $0.0005 * * *$ & 5.74 & $0.08 * * *$ & 5.08 \\
\hline GDP growth rate & $-0.0003 * *$ & -2.54 & $0.06^{* * * *}$ & 2.78 \\
\hline F test & \multicolumn{2}{|l|}{$342.70 * * *$} & \multicolumn{2}{|l|}{$1719.92 * * *$} \\
\hline Sargan test & \multicolumn{2}{|l|}{68.28} & \multicolumn{2}{|l|}{38.6} \\
\hline $\mathrm{AR}(1)$ & -5.99 & 0.000 & -3.58 & 0.000 \\
\hline $\mathrm{AR}(2)$ & -0.79 & 0.431 & -1.50 & 0.134 \\
\hline No. of observations & \multicolumn{2}{|l|}{409} & \multicolumn{2}{|l|}{387} \\
\hline
\end{tabular}

$*, * *$ and $* * *$ denote significance at $10 \%, 5 \%$ and $1 \%$ levels, respectively. 
Table 11 Empirical results: The impact of competition on bank profitability (state-owned banks and all indicators)

\begin{tabular}{|c|c|c|c|c|}
\hline & \multicolumn{2}{|l|}{ ROA } & \multicolumn{2}{|l|}{ NIM } \\
\hline & coefficient & t-statistic & Coefficient & t-statistic \\
\hline Lag of dependent variable & $0.47 * * *$ & 3.60 & $0.27 * *$ & 2.46 \\
\hline \multicolumn{5}{|l|}{ Bank characteristics } \\
\hline Credit risk & 0.001 & 1.29 & -0.06 & 0.91 \\
\hline Liquidity & $0.001 * *$ & 2.18 & 0.02 & 0.48 \\
\hline Capital & $-0.03 * *$ & -2.39 & 0.45 & 0.31 \\
\hline Insolvency risk & -0.01 & -1.33 & 1.002 & 0.98 \\
\hline Bank size & -0.00002 & -0.01 & 0.02 & 0.10 \\
\hline Overhead cost & 0.16 & 0.55 & $98.13^{*}$ & 1.98 \\
\hline Bank diversification & 0.00001 & 0.24 & $-0.03 * * *$ & -3.70 \\
\hline \multicolumn{5}{|l|}{ Industry characteristics } \\
\hline Boone indicator (loan) & $-7.88 * *$ & -2.35 & $-806.5^{*}$ & -1.78 \\
\hline Boone indicator (deposit) & $11.03 * * *$ & 2.82 & $357.87 *$ & 1.72 \\
\hline $\begin{array}{l}\text { Boone indicator (non- } \\
\text { interest income) }\end{array}$ & -0.83 & -0.63 & 225.48 & 0.28 \\
\hline $\begin{array}{l}\text { Banking sector } \\
\text { development }\end{array}$ & 0.004 & 1.18 & -0.06 & -0.12 \\
\hline $\begin{array}{l}\text { Stock market } \\
\text { development }\end{array}$ & -0.00004 & -1.53 & -0.006 & -1.57 \\
\hline \multicolumn{5}{|l|}{ Macroeconomics } \\
\hline Inflation & 0.0002 & 0.68 & $0.09 * *$ & 2.65 \\
\hline GDP growth rate & -0.0005 & -1.29 & 0.06 & 1.02 \\
\hline F test & \multicolumn{2}{|l|}{$129.90 * * *$} & \multicolumn{2}{|l|}{$370.46 * * *$} \\
\hline Sargan test & \multicolumn{2}{|l|}{48.79} & \multicolumn{2}{|l|}{48.21} \\
\hline $\mathrm{AR}(1)$ & -0.31 & 0.760 & -0.49 & 0.662 \\
\hline $\mathrm{AR}(2)$ & -1.28 & 0.200 & -0.45 & 0.654 \\
\hline No. of observations & \multicolumn{2}{|l|}{40} & \multicolumn{2}{|l|}{41} \\
\hline
\end{tabular}

$*, * *$ and $* * *$ denote significance at $10 \%, 5 \%$ and $1 \%$ levels, respectively. 
Table 12 Empirical results: The impact of competition on bank profitability (joint-stock banks and all indicators)

\begin{tabular}{|c|c|c|c|c|}
\hline & \multicolumn{2}{|l|}{ ROA } & \multicolumn{2}{|l|}{ NIM } \\
\hline & coefficient & t-statistic & Coefficient & t-statistic \\
\hline Lag of dependent variable & 0.16 & 1.12 & $0.29 * * *$ & 3.59 \\
\hline \multicolumn{5}{|l|}{ Bank characteristics } \\
\hline Credit risk & 0.0002 & 0.69 & 0.013 & 0.71 \\
\hline Liquidity & $0.0004 * *$ & 2.40 & 0.03 & 1.62 \\
\hline Capital & 0.0004 & 0.08 & 0.14 & 0.25 \\
\hline Insolvency risk & -0.00005 & -0.01 & $1.28^{*}$ & 1.95 \\
\hline Bank size & 0.01 & 1.36 & $0.22 * *$ & 2.86 \\
\hline Overhead cost & 0.16 & 0.91 & $107.13 * * *$ & 5.54 \\
\hline Bank diversification & $0.0001 *$ & 1.87 & $-0.01 * *$ & -2.04 \\
\hline \multicolumn{5}{|l|}{ Industry characteristics } \\
\hline Boone indicator (loan) & $-4.75^{*}$ & -1.71 & $-752.22 * *$ & -2.66 \\
\hline Boone indicator (deposit) & $4.43 *$ & 1.70 & 114.66 & 1.26 \\
\hline $\begin{array}{l}\text { Boone indicator (non- } \\
\text { interest income) }\end{array}$ & 0.43 & 0.36 & $292.5^{* *}$ & 2.67 \\
\hline $\begin{array}{l}\text { Banking sector } \\
\text { development }\end{array}$ & -0.002 & -0.91 & $-0.66 * * *$ & -3.10 \\
\hline $\begin{array}{l}\text { Stock market } \\
\text { development }\end{array}$ & -0.00004 & -1.57 & $-0.009 * * *$ & -3.50 \\
\hline \multicolumn{5}{|l|}{ Macroeconomics } \\
\hline Inflation & 0.0001 & 0.72 & $0.11 * * *$ & 6.39 \\
\hline GDP growth rate & 0.00004 & 0.15 & $0.09 * * *$ & 3.42 \\
\hline F test & \multicolumn{2}{|l|}{$84.44 * * *$} & \multicolumn{2}{|l|}{$776.77 * * *$} \\
\hline Sargan ( $\mathrm{p}$ value) & \multicolumn{2}{|l|}{42.84} & \multicolumn{2}{|l|}{94.98} \\
\hline $\mathrm{AR}(1)$ & -2.47 & 0.013 & -2.14 & 0.032 \\
\hline $\mathrm{AR}(2)$ & -0.98 & 0.329 & 0.57 & 0.570 \\
\hline No. of observations & \multicolumn{2}{|l|}{65} & \multicolumn{2}{|l|}{66} \\
\hline
\end{tabular}

$*, * *$ and $* * *$ denote significance at $10 \%, 5 \%$ and $1 \%$ levels, respectively. 
Table 13 Empirical results: The impact of competition on bank profitability (city banks and all indicators)

\begin{tabular}{|c|c|c|c|c|}
\hline & \multicolumn{2}{|l|}{ ROA } & \multicolumn{2}{|l|}{ NIM } \\
\hline & coefficient & t-statistic & Coefficient & t-statistic \\
\hline Lag of dependent variable & $0.07 * *$ & 2.05 & $0.61 * * *$ & 6.71 \\
\hline \multicolumn{5}{|l|}{ Bank characteristics } \\
\hline Credit risk & -0.0001 & -1.24 & 0.013 & 0.31 \\
\hline Liquidity & 0.0001 & 0.49 & $0.036^{* *}$ & 2.20 \\
\hline Capital & -0.003 & -1.09 & -0.6 & -0.56 \\
\hline Insolvency risk & -0.002 & -0.48 & -0.27 & -0.36 \\
\hline Bank size & -0.0001 & -0.22 & $-0.14 *$ & -1.93 \\
\hline Overhead cost & $0.15^{* *}$ & 2.26 & $110.27 * * *$ & 6.50 \\
\hline Bank diversification & $0.00005 * *$ & 2.46 & $-0.03 * * *$ & -3.78 \\
\hline \multicolumn{5}{|l|}{ Industry characteristics } \\
\hline Boone indicator (loan) & $-5.01 * * *$ & -3.35 & -197.37 & -0.63 \\
\hline Boone indicator (deposit) & $5.99 * * *$ & 2.96 & 293.5 & 1.43 \\
\hline $\begin{array}{l}\text { Boone indicator (non- } \\
\text { interest income) }\end{array}$ & -0.06 & -0.09 & -20.7 & -0.17 \\
\hline $\begin{array}{l}\text { Banking sector } \\
\text { development }\end{array}$ & $0.006 * * *$ & 4.20 & 0.1 & 0.30 \\
\hline $\begin{array}{l}\text { Stock market } \\
\text { development }\end{array}$ & $-0.00002 *$ & -1.76 & $-0.006 * *$ & -2.03 \\
\hline \multicolumn{5}{|l|}{ Macroeconomics } \\
\hline Inflation & $0.0004 * * *$ & 2.82 & $0.07 * * *$ & 2.72 \\
\hline GDP growth rate & $-0.0003 *$ & -1.71 & $0.1 * * *$ & 3.10 \\
\hline F test & \multicolumn{2}{|l|}{$206.08 * * *$} & \multicolumn{2}{|l|}{$772.58 * * *$} \\
\hline Sargan(p value) & \multicolumn{2}{|l|}{48.94} & \multicolumn{2}{|l|}{36.95} \\
\hline $\mathrm{AR}(1)$ & -4.50 & 0.000 & -3.50 & 0.000 \\
\hline $\mathrm{AR}(2)$ & -0.77 & 0.442 & -1.42 & 0.155 \\
\hline No. of observations & \multicolumn{2}{|l|}{304} & \multicolumn{2}{|l|}{208} \\
\hline
\end{tabular}

$*, * *$ and $* * *$ denote significance at $10 \%, 5 \%$ and $1 \%$ levels, respectively. 